\title{
The Improvement of the Bunton Construction of Mine-shaft Equipment
}

\author{
Kopytov Aleksandr I. ${ }^{\mathrm{a}}$, Pershin Vladimir V., , Voitov Michail D. ${ }^{\mathrm{b}}$, Wetti Ahmed A ${ }^{\mathrm{b}}$. \\ T. F. Gorbachev Kuzbass State Technical University \\ Kemerovo, Russian Federation \\ ae-mail: L01BDV@yandex.ru, be-mail: wetti_a@mail.ru
}

\begin{abstract}
Shaft equipment plays an important role in the process of exploitation loading. The main load is concentrated on the basic buntons, which are horizontal metal H-beams and they are fixed into the shaft support by both ends. In shafts with skip hoisting of useful minerals the destruction of upper flanges of buntons from multiple frontal impacts of rock pieces weighing $150-200 \mathrm{~kg}$, the impact of mine water drip and corrosion is observed. As a result, it is necessary to change shaft equipment during working life of a mine shaft.

In order to reduce the magnitude of push loading from falling pieces of rock and ore spillage, effects of corrosion and reduction of labor costs for repair and reconstruction works the construction of bunton for stiff metal shaft equipment was developed, in which the horizontal flange of $\mathbf{H}$-beam is protected by a firmly fixed metallic bracket. The bracket reduces the kinetic energy of the falling pieces of ore or rock spillage in the shaft with skip hoisting; as a result, the bunton working life is prolonged. The construction can be used for shaft equipment of vertical shafts of coal and ore mines.
\end{abstract}

Keywords - vertical shaft, stiff shaft equipment, skips hoisting, bunton, horizontal flange, protection, metal bracket

\section{INTRODUCTION}

The necessity to reinforce vertical shafts is due to the increased depth of deposits development and the improvement of loading methods of useful minerals from the mine to the surface. At the end of the $15^{\text {th }}$ century, vertical shafts of rectangular cross-section were supported by close-set wooden timbering. At that time equipment of a shaft had been done to create bout gate and cargo compartments in its cross section, which also consisted of wooden structural elements [1].

For a long period of development of the technology of underground mining of mineral resources, the intensity of development of coal and iron ore deposits has increased significantly [2, 3]; powerful loading equipment ensuring productivity and profitability of underground mines and open pits in the market economy conditions was created.

In construction, reconstruction and operation practice of modern mining enterprises with underground mining operations metal shafts equipment consisting of shaft conductors and buntons was widely used.

The greatest load is on the main buntons which are mainly made of metal H-beams and are installed with fixation of beam ends in the shaft support by horizons $[4,5]$.
In the shafts with skip hoisting, inevitable spillage of pieces weighing up to $200 \mathrm{~kg}$ during the loading process, skips movement along the shaft, and unloading process is observed.

As a result of local impacts on the upper flange of the buntons, the consequent impact of mine water drip and corrosion, the destruction processes begin, they lead to the necessity to repair or replace the buntons during operation of the shaft.

The aim of this work is to improve the design of buntons, the design of the equipment of vertical shafts, which will reduce the impact loading and the impact of corrosion on the upper flange of H-beams, and significantly reduce labor costs for repairing works.

\section{RESEARCH RESULTS}

Construction, reconstruction and operation experience of underground mines and open pits shows that under the construction of vertical shafts the stiff shaft equipment was widely used.

In shafts, equipped by skip hoisting with large suspended load, metal equipment of the shaft is used; metal equipment is composed of buntons and shaft conductors.

Buntons are divided into the main type - when the conductors are fastened to them to guide travelling hoisting vehicle; and the auxiliary type - when they are used to install boutgate on them and pipes and cables equipment and so on. The main buntons are fixed by both ends in the shaft support [6-8].

H-beam buntons are used for shafts with definite depth and production capacity; box form buntons are used for deep shafts and shafts with large production capacity (Table 1).

Box section has a number of advantages in comparison with an H-beam one: a higher resistance moment in the horizontal plane with the same section mass, a higher rotational moment, corrosion influence decrease, corrosion which at the H-beam section spreads all over the section perimeter, but at a box section corrosion spreads only over the outward edge. 
TABLE 1. Sections, sizes and main indices of beams buntons

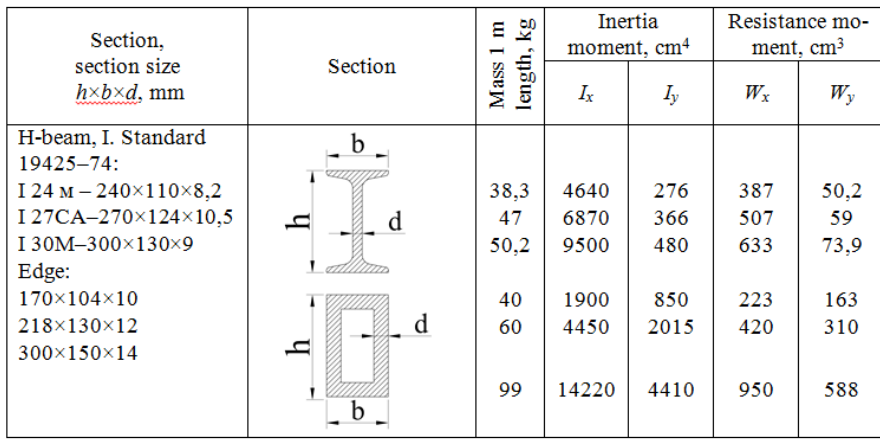

Notice: $h, b, d$ - height, width and section thickness.

H-beam buntons can be made of different length pieces, which can be regulated under potential shaft support deformation (Fig. 1).
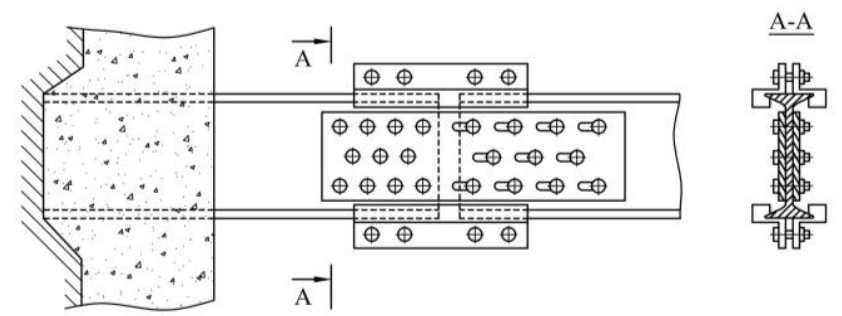

Fig. 1. Compound bunton with regulated length
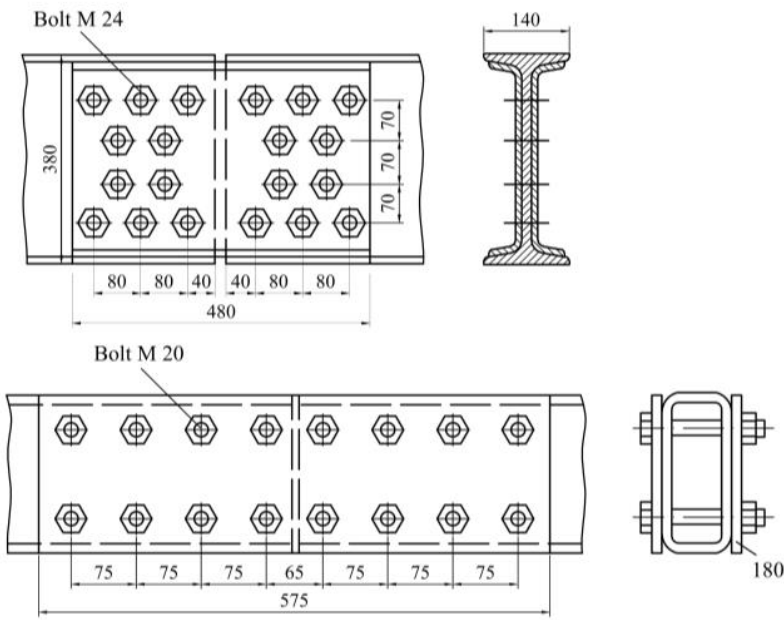

Fig. 2 Constructions of compound bunton

There upper flange buntons are destructed due to numerous frontal impacts of rock pieces with mass of 150-200 kg in shafts with skip hoisting of minerals.

Corrosion of metal bracket elements can occur as a result of such load actions on the upper flanges of the buntons, as a result of mine water drip with sulfate ions or higher index of hydrogen. Damage rate of bunton walls and conductors due to corrosion varies from 0.03 to $0.16 \mathrm{~mm}$ per year. At this rate of shaft equipment failure, it is required to perform equipping of the shaft two or three times over the shaft service life with a strict control of its condition [9].

Initially, the tendency of destruction of the upper flanges of buntons is observed during construction and then during shaft deepening and parallel installation of the shaft equipment when heavy objects fall, despite the usage of the protecting devices [10-13].

This was identified in operation of the Skipovoy skip shaft at the Mountain Shoria branch of OJSC Evrasruda. The Skipovoy skip shaft was sunken from the spot level $+630 \mathrm{~m}$ to the spot level $+115 \mathrm{~m}$ and was put into operation in 1982. In 2013 the works of the shaft extension were finished to the spot level $-85 \mathrm{~m}$.

The adopted shaft equipment scheme took into account the shaft operation for mining at the overlying levels (Fig.3). The run-of-mine ore is lifted from the prepared levels by two $2 \mathrm{ChNi}-20$ skips with capacity of $20 \mathrm{~m}^{3}$, and rock is lifted by two rock skips $2 \mathrm{ChNi}-7,5$ of $7 \mathrm{~m}^{3}$ capacity.

$\mathrm{H}$-beam $36 \mathrm{M}$ is taken as a buntons based on the calculations [4].

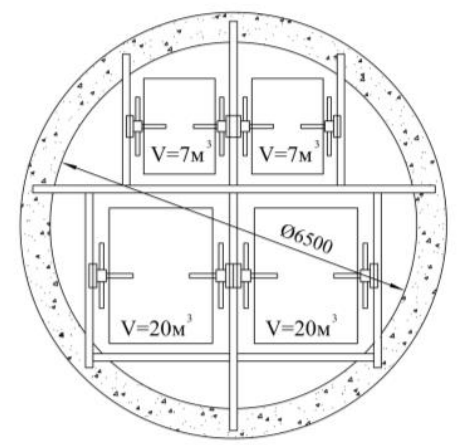

Fig. 3 "Skipovoy" shaft equipment

During H-beams buntons operation to protect the upper horizontal flanges from local impacts, the protective canopies made of resilient slotted pipes connected by springs can be used; these springs press the protective canopies to the horizontal flanges of H-beams buntons.

These dome constructions are installed under the upper and lower flanges of the bunton by the convex face up and down respectively to reduce the aerodynamic resistance of the air in deep shafts and to increase operational reliability by increasing the stability of the body $[15,16]$.

The considerable draw backs of such buntons are their complex structure, high metal consumption, and potential destruction under load action of rock impacts when rock is falling out of the skips.

To make the structure simple, to reduce metal consumption and the value of the impact from falling pieces of rock and rock spill, the bunton was developed with its horizontal flange protected by a rigid fixed metal bracket (Fig. 4).

The bunton of shaft equipment contains a beam 1 with horizontal flange 3 , where the protective canopy from metal bracket 5 is fixed toughly; the rib of the bracket is directed upwards. 
The bunton mass with the beam 1 of bracket 5 fixed on flange 3 increases nominally in comparison with the resistance moment increase; this excludes bunton destruction under direct but rare falling pieces of rock and rock spill on the rib 6 of the bracket 5 .

In most cases when pieces of rock and rock spill fall on the bunton, the impulse load is received to the inclined planes of the bracket 5 . The kinetic energy is not fully damped in this case, but the energy of rock falling is only reduced, it is connected with direction of slope alteration. Impact load of repulsion is of small account.

Minor constructional complication of a bunton due to installation and fixation of bracket 5 on flange 3 of beam 1 increases greatly the service life of the bunton of the shaft equipment [17].

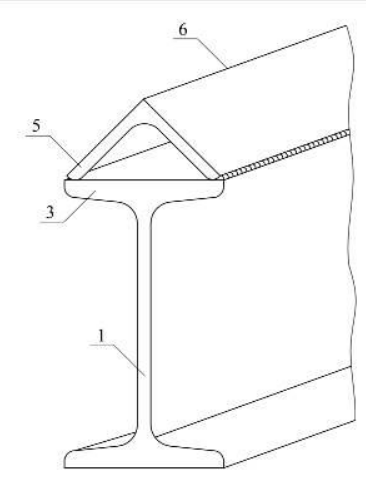

Fig. 4 New bunton construction of mine-equipment shafts

\section{CONCLUSION}

The construction of a bunton of stiff shaft equipment of vertical shafts was developed, with the upper flange of $\mathrm{H}$ beam, protected by strictly fixed metal bracket.

The inclined surfaces formed by the bracket, allow damping the kinetic energy of falling pieces of rock and ore spillage in the shafts with skip hoisting, to protect the upper flange of H-beam from any local frontal impacts, or impacts of mine water drip. The angle allows increasing the carrying capacity and prolonging the operation life of a bunton. The design of the bunton can be used in the construction of enterprises of coal mining industry.

\section{REFERENCES}

[1] Kopytov A. I., Masaev Yu. A., Pershin V. V. Istoriya razvitiya gornogo dela [The history of mining development] Novosibirsk, Nauka. 2009. 511 p.

[2] Kovalev V. A., Kopytov, A. I., Pershin V. V. Mineral'no syr'evye resursy vazhnyy potentsial innovatsionnogo razvitiya ugol'no-metallurgicheskogo kompleksa Kuzbassa [Mineral resources - an important potential for innovative development of coal and metallurgical complex of Kuzbass] Moscow : «Ugol'», 2014, № 2. - p. 6-9.

[3] 井巷快速掘进爆破新技术 Kopytov A. I., Efremov A. V., Pershin V. V., Kopytov M. A., Sposoby i sredstva intensifikatsii gornoprokhodcheskikh rabot na rudnikakh [Ways and means of intensification of mining operations at the ore mines] Beijing, China. 2005. 312 p.

[4] Kartoziya B. A., Fedunets B. I., Shuplyak M. N. Shakhtnoe i podzemnoe stroitel'stvo. Tom I [Mining and Underground Construction]. Moscow. 2001. $608 \mathrm{p}$.

[5] Baronskiy, I. V., Kosarev N. F., Pershin V. V., Kopytov A. I. Shakhtnoe stroitel'stvo v Kuzbasse [Mine construction in Kuzbass]. Kemerovo, Kuzbassvuzizdat. 2006. 543 p.

[6] Pokrovskiy, N. M. Kompleksy podzemnykh gornykh vyrabotok i sooruzheniy[Complexes of underground mine yield and structures]. Moscow, «Nedra». 1987. $248 \mathrm{p}$.

[7] Pershin, V. V., Kopytov A. I. Sarychev V. I. Stroitel'stvo i uglubka vertikal'nykh stvolov shakht [Construction and hole making vertical shafts]. Novosibirsk, «Nauka». 2014. 351 p..

[8] Pershin, V. V., Kopytov A. I. Sarychev V. I. Rekonstruktsiya gornykh predpriyatiy [Reconstruction of mining enterprises]. Novosibirsk, «Nauka». 2014. 204 p.

[9] Federal'nye normy i pravila $\mathrm{v}$ oblasti promyshlennoy bezopasnosti «Pravila bezopasnosti v ugol'nykh shakhtakh». Seriya 05. Vypusk 40 [safety regulations in coal mines] - Moscow ZAO NTTs issledovaniy problem promyshlennoy bezopasnosti, 2014. - $200 \mathrm{p}$

[10] Kopytov, A. I., Zhuk I. V., Voytov M. D., Morozov S. S. Klinovoy predokhranitel'nyy polok pri uglubke vertikal'nykh stvolov shakht [The wedge safety shelves when deepening vertical shafts] Patent № 120706. Reiterated in State list-register of useful models of the Russian Federation at 27.09.2012.

[11]Kopyitov A. I., Pershin V. V., Voitov M. D., Wetti A. A., Zhuk I. V. Constructions parameters updating of protecting apron under deepening of vertical shafts. Taishan Academic Forum - Project on Mine Disaster Prevention and Control. October 17-20, 2014. Qingdao, China. p. 21-24.

[12]Kopytov, A. I., Voytov M. D., Wetti A. A. Novye tekhnologicheskie resheniya predokhranitel'nykh ustroystv dlya uglubki vertikal'nykh stvolov shakht [New technological solutions for safety devices deepening mining vertical shafts] Moscow, «Gornyy zhurnal», 2015. No 1. p. 67-70.

[13] Kopytov, A. I., Pershin V. V., Voitov M. D., Wetti A. A. Razrabotka zashchitnykh ustroystv, tekhnologii ikh sooruzheniya i demontazha pri uglubke vertikal'nykh stvolov [Development of protective devices, the technology of their construction and dismantling when deepening ertical shafts] Moscow «Ugol'», 2015. No 9. p. 51-55.

[14] Kopytov, A. I. Kurkin A. O. Armirovanie stvola «Skipovoy» pri rekonstruktsii Gorno-Shorskogo filiala OAO «Evrazruda» [Shaft equipment of «Skipovoy» under reconstruction of Mountain Shoria branch of OJSC «Evrasruda»] Kemerovo, Vestnik Kuzbass. gosud. tehn. univ. 2014. No 6. p. 47-50.

[15] Kirin, R. S. Obtekatel' rasstrelov shakhtnykh stvolov [Fairing bunton mine shafts equipment]. Patent USSR № 1726748 A1, E21D 7/02, 15.04.92. Byul. No 14

[16] Kirin, R. S. Obtekatel' shakhtnykh rasstrelov dvutavrovogo profilya [Fairing mine I-profile mine shafts equipment]. Patent USSR No 1789703 A1, E21D 7/00, 23.01.93. Byul. № 3.

[17] Kopytov A. I., Voytov M. D., Veti A. A. Rasstrel armirovki shakhtnogo stvola [Shaft equipment bunton]. Patent № 155223. Reiterated in State list-register of useful models of the Russian Federation at 02.09.2015. 